World Lumen Congress 2021 | May 26-30, 2021 |

Iasi, Romania

\title{
Cryptocurrency (Virtual Coins): Accounting Aspects and Tax Regulations
}

\author{
Adriana Monica ȚEGLEDI, Boni Mihaela STRAOANU \\ https://doi.org/10.18662/wlc2021/64
}

How to cite: T,egledi, A. M., \& Straoanu, B. M. (2021). Cryptocurrency (Virtual Coins): Accounting Aspects and Tax Regulations. In A. Sandu (vol. ed.), Lumen Proceedings: Vol. 17 World Lumen Congress 2021 (pp. 650-657). Iasi, Romania: LUMEN Publishing House. https://doi.org/10.18662/wlc2021/64 


\title{
Cryptocurrency (Virtual Coins): Accounting Aspects and Tax Regulations
}

\author{
Adriana Monica ȚEGLEDI ${ }^{1}$, Boni Mihaela STRAOANU²
}

Abstract

Lately, there have been many questions from specialists regarding the accountability of cryptocurrency. The lack of a legislation has allowed them to be interpreted as either intangible assets or stocks, even though Romania owns the biggest transaction platform in Eastern Europe (Bitcoin Romania).

National Bank of Romania (NBR) acknowledges the lack of regulations and supervisions regarding cryptocurrency, regarding them as "speculative assets, extremely volatile and risky". Simultaneously, this brings to attention the fact that these are not national coins nor currencies, and accepting them as a payment method isn't, legally speaking, mandatory.

Keywords: Intangible assets, stocks, currencies.

\section{Introduction}

Authorities across the globe have tried to define virtual coins, adopting different positions regarding their nature. These authorities have defined them as goods, banking regulators and supervisors considered them coins and tax authorities have classified crypto coins as financial instruments used by investors for a portfolio diversification (Tucker, 2017).

The issue addressed in this article is represented by virtual currencies, which are analyzed both from an accounting and fiscal point of view (Berentsen \& Schär, 2018). The article is structured in two parts: the first part is represented by the definition of the term virtual currencies, and the second part includes aspects regarding their registration in accounting, as well as fiscal interpretations.

\section{Defining virtual currencies at EU level (including UK)}

Regarding the opinions of European countries in regulating this virtual coin we can say that: in Belgium ${ }^{3}$, Croatia and Malta it is not considered legal currency

\footnotetext{
${ }_{1}^{1}$ Associate professor, Petroleum and Gas University of Ploiesti, Romania. monica tegledi@yahoo.com

${ }^{2}$ Associate professor, Petroleum and Gas University of Ploiesti, Romania. boni.straoanu@gmail.com

3 https://www.nbb.be/doc/ts/enterprise/press/2014/cp140114en.pdf
} 
("legal tender"), nor electronic currency, in the Czech Republic ${ }^{4}$, Bitcoin currency is not classified as banknote, coin, scriptural coin or electronic coin, in Denmark it's not recognized as a currency, in Germany ${ }^{5}-$ it is considered as an account unit which can be used for private transactions, is not considered legal tender, but it is a financial instrument, in Estonia ${ }^{6}$ - "Bitcoin is not a legal tender, but an alternative means of payment". In Spain "it is not considered a legal tender, since it is not issued by the governmental monetary authority"; in France ${ }^{8}$ - transactions with this currency are considered a form of service provision ${ }^{9}$ for which a payment service ${ }^{10}$ provider license is required, and for income "from the sale of Bitcoin to a personal bank account, the bank will complete a statement to the Anti-Money Laundering Agency $^{11}$ " . In Luxembourg, this is not considered a legal tender, electronic currency or regular currency, and companies wishing to operate in the financial sector (including the provision of payment services using virtual currencies or setting up trading platforms) must seek authorization from the Minister of Finance and to be supervised by the Financial sector's authorities.

Italy's position on the Bitcoin system is identical to that adopted by the EU. Thus, on the 29th of October 2002, "the European Central Bank published the "Report of Virtual Currency ${ }^{12}$ (European Central Bank, 2012), "which presents the relevant economic and legal aspects of the Bitcoin system". A 2009 "European directive regulates the use of electronic money (including Bitcoin) in order to harmonize payment methods, increase competition and facilitate market access ${ }^{13}$, , "which defines the concept of electronic money, including cases where it is issued electronically in exchange for funds to be used as a means of payment and also identifies the people who are authorized to issue electronic money" (Yermack, 2013).

ECB defines virtual currencies as "a digital representation of value that is not issued by a central bank, a credit institution or an electronic money institution, which, in certain circumstances, can be used as an alternative to money" (Athanassiou, 2017). In the ECB's opinion, “ virtual coins are not money or currency", legally speaking. The use of electronic currencies is "allowed by the central banks of the European members, the Italian public administration at regional and local government level and the Italian postal system. However, the use of electronic money is limited to banks and virtual monetary institutions - i.e.,

\footnotetext{
4 https://www.cnb.cz/miranda2/export/sites/www.cnb.cz/cs/faq/obchodovani_s bitcoiny.pdf

5 https://www.theguardian.com/technology/2013/aug/19/bitcoin-unit-of-account-germany

6https://www.bloomberg.com/news/articles/2014-01-30/bitcoin-ponzi-scheme-worry-sparksestonia-central-bank-caution

7 https://www.loc.gov/law/help/bitcoin-survey/\# ftnref121

8 https://bnro.ro/apage.aspx?pid=12132

9 https://bnro.ro/Pozitiile-exprimate-de-catre-statele-europene-cu-privire-la-monedele-virtuale12132.aspx

${ }^{10}$ https://acpr.banque-france.fr/searches?term $=20140129+$ Communique + ACPR + position + bitcoin

${ }^{11}$ https://www.coindesk.com/france-bitcoin-revenues-must-declared-tax-authorities

12 http://www.ecb.europa.eu/pub/pdf/ other / virtualcurrencyschemes201210en.pdf

13 http://eur-lex.europa.eu/ LexUriServ / LexUriServ.do? Uri = OJ: L: 2009: 267: 0007: 0017: RO: $\underline{\mathrm{PDF}}$
} 
private legal entities duly authorized and registered by the Central Bank of Italy".

"Apart from these developments, Italy does not regulate the use of Bitcoin by private individuals". In Sweden (De La Paz, 2013), it is considered active, not currency, and transactions with this currency will be tracked by the Financial Surveillance Authorities ${ }^{14}$. In the UK, virtual currencies have a limited role as money, for relatively few users ${ }^{15}$.

The first international studies on the nature of virtual coins were conducted by Venter H., in (2018) - "Digital Currency - A Case for Standard Setting Activity", analyzing the possibility of classifying cryptocurrencies in the asset classes already existing in international regulations based on IFRS and concluded that they are not currencies in the sense given by IAS 7, "the statement of cash flows", nor financial instruments in the sense given by IAS 32 "Financial Instruments: Presentation" or IFRS 9 "Financial Instruments" $"$.

Nationally, several authors have dealt with how earnings from cryptocurrency transactions are taxed: Milcev, A. (2018a), Four tax issues to be taken into account before launching an ICO offer, Milcev, A. (2018b), Cryptocurrency trading - a market far too large to stay out of tax law, Paunescu, M. (2018a), Exploratory Study on Accounting and Taxation of Virtual Currencies by Romanian Companies, Păunescu, M. (2018b), Taxation of virtual currency transactions in the case of Romanian companies applying IFRS, Păunescu, M. (2018b, The Accountant's Headache: Accounting for Virtual Currencies Transactions, The attraction of cryptocurrencies and the inevitable taxation, but also large consulting firms addressed this issue: Deloitte - "Cryptocurrencies and the first specific regulation of national legislation by the fiscal code"17, "Regulators can no longer ignore cryptocurrencies"18, "Digitalization is coming upon us but regulations are delayed"19.

\section{The issue of cryptocurrency accounting in Romania according to accounting and tax legislation.}

A first regulation on virtual currency appears with Law 30/2019 (Romanian Parliament, 2015), but aims to tax the gain from virtual currency transactions of individuals, being considered income from other sources.

Fiscal $\operatorname{code}^{20}$ (European Central Bank, 2015) art. 47, provides that individuals who make profits from transactions with cryptocurrencies have to pay a $10 \%$ income tax, applied to the difference between the income obtained and the amount

\footnotetext{
${ }^{14}$ http://archive.riksbank.se/Documents/Rapporter/Riksbanksstudie/2013/rap riksbanksstudie T

he Swedish retailpayment market 130605 eng.pdf

15 https://www.fca.org.uk/news/news-stories/european-warning-virtual-currencies

16 https://www.fca.org.uk/news/news-stories/european-warning-virtual-currencies

${ }^{17}$ www2.deloitte.com/“criptomonedele-si-prima-reglementare-specifica-din-legislatia-nationala-prin-codul$\underline{\text { fiscal" }}$

${ }^{18 h t t p s: / / w w w 2 . d e l o i t t e . c o m / “ i ̂ n c e p u t-d e-c a p i t o l-r e g l e m e n t a t o r i i-n u-m a i-p o t-i g n o r a-c r i p t o m o n e d e l e " ~}$

${ }^{19}$ https://www.zf.ro/-"digitalizarea-vine-peste-noi-dar-reglementarile-intarzie"

${ }^{20}$ Law no. 225/2015 regarding Fiscak Code, updated through EGO no. 19/25.03.2021
} 
invested. This tax does not apply if:

- The individual keeps his earnings from cryptocurrencies in the form cryptocurrencies, so he does not convert them into RON or other currencies or use them to buy goods, works or services;

- If no gains in excess of RON 200 were obtained from their trading per transaction or RON 600 per year.

If earnings are obtained that exceed these values, individuals have the obligation to declare them to the tax authorities and to submit the single declaration by the 25th of May. If the value of the earnings exceeds the sum of RON 27,600 (the equivalent of 12 salaries gross minimum) they must also pay the $10 \%$ health contribution.

As far as legal persons are concerned, we need to determine how we can classify these cryptocurrencies in accordance with OMFP 1802/2014 and international regulations (Jabotinsky, 2018).

For the accounting of cryptocurrencies, France has introduced new accounting policies for when they are considered intangible assets, short-term investments held for investment purposes or when used to pay for the goods or services purchased (I specifically mentioned this system, seeing how Romania has adopted the French accounting system).

What are the transactions that can take place using cryptocurrencies?

- can be purchased for investment purposes;

- can be bought or sold in exchange for fiat money;

- mining;

- is used for the collection of services, works or goods sold;

- can be used for payment of debts: suppliers, employees;

- loans can be granted;

- loans can be received;

- there are ATMs and cryptocurrency-centric banks;

- there are platforms on which they are exchanged;

- ICO("Initial Coin Offering"), STO ("Security Token Offering"), IEO ("Initial Exchange Offering") ${ }^{21}$;

- hedging funds for cryptocurrencies ${ }^{22}$.

According to the national regulations ("OMFP 1802/2014 for the approval of Accounting regulations on individual annual financial statements and consolidated annual financial statements"“Law no. 225/2015 (Romanian Parliament, 2015) regarding the Fiscal Code“"“Ordinance of emergency no. 111 of July 1, 2020 on amending and supplementing Law no. 129/2019 for preventing and combating money laundering and terrorist financing" $)$, from the point of view of their inclusion in the general chart of accounts:

- cryptocurrencies cannot be considered currency - money - "legal tender",

\footnotetext{
${ }^{21}$ https://accountinghub.ro/cum-inregistram-in-contabilitate-tranzactiile-cu-criptomonede

${ }^{22} \mathrm{Idem}$
} 
because they do not meet the criteria: they are not supported or issued by the Government, they are not legal means of payment (Vardi, 2016);

- they cannot be classified as cash equivalents because they are not shortterm financial investments (up to 3 months) which can be converted at any time into $\operatorname{cash}^{23}$;

- they may be classified as financial instruments - but are not shares, bonds or other investments, because they do not represent a contract that simultaneously generates a "financial asset for an entity and a financial liability or an instrument of equity for another entity ${ }^{24 ،}$. There may be situations when cryptocurrencies are the subject of a contract in which one party decides to sell and the other party decides to buy cryptocurrencies;

- are intangible assets - according to art. 138. - fixed assets are assets generating future economic benefits and art. $144^{25}$. - "an intangible immobilization is an identifiable non-monetary asset without physical form". Art. 150. - "specifies that an asset is identifiable if: a) it is separable, i.e. it can be separated or detached from the entity and sold, transferred, assigned by contract license, leased or exchanged, either individually or in conjunction with another contract, with an identifiable asset or a related identifiable liability, regardless whether or not the entity intends to do so""; or b) arises from contractual or other legal rights, whether those rights are transferable or separable from the entity or other rights and obligations";

- are current assets - stocks when they are held by a unit for the purpose of sale, given that it meets the conditions provided by the law, art. 272. - Stocks are current assets: a) "held to be sold during the normal course of business; b) in the process of production for sale in the normal course of business; or c) in the form of raw materials, materials and other consumables to be used in the production process or for the provision of services".

According to the Emergency Ordinance no. 111 from the 1st of July 2020 on the amendment and completion of "Law no. 129/2019 (Romania Parliament, 2019) for preventing and combating money laundering and financing terrorism", providers involved in exchange services between virtual currencies and fiat money have obligations related to the identification of suspicious activities, namely recognizing clientele, identification of the real beneficiary, monitoring and reporting to the authorities of certain transactions.

Which accounts are the ones used to record transactions in the accounts?

\section{If we consider digital currencies as goods:}

a. Acquisition of cryptocurrencies: 371 Goods $=401$ Providers

b. Provider's payment. 401 Providers $=5121$ Money Accounts in RON

c. Selling cryptocurrencies: 4111 Clients $=707$ Incomes from the selling of goods

\footnotetext{
${ }^{23}$ Ibidem

${ }^{24}$ Ibidem

25 OMFP 1802/2014 for "the approval of accounting regulations on individual annual financial statements and consolidated annual financial statements"
} 
Adriana Monica ȚEGLEDI et al.| Lumen Proceedings 17 | WLC 2021

d. Receivable's collection: 512 Money Accounts in RON $=4111$ Clients

e. Management download: 607 Expenditures regarding goods $=371$ Goods

\section{An economic unit providing services is paid in cryptocurrencies:}

a. Invoice registration: 4111 Clients $=704$ Service Incomes

b. Bitcoin Cash-In: 581 Internal Transfers $=4111$ Clients; 371 Bitcoin $=581$ Internal Transfers

c. If Bitcoin is cashed in currency: 581 Internal Transfers = 371 Bitcoin; 5124 Bank Accounts in Foreign Currency $=581$ Internal Transfers

\section{Conclusions}

With the increase in popularity and interest shown by both individual and legal persons regarding transactions with cryptocurrencies, it is possible that governments will get involved in regulating them, as they can compete directly with commercial banks in the future.

This paper tried to highlight certain fiscal and accounting aspects regarding cryptocurrencies, but also noticed the lack of regulations in the field.

The main contribution of this paper consists in the notions extracted from the literature of specialty on activities with virtual currencies.

Therefore, this work should not be seen as a complete treatment and comprehensive research and taxation of cryptocurrencies; future research needs to be done to provide additional information on the potential for virtual currencies to become a secure asset, as well as on technical specificities such as mining concentration and validation and confirmation processes - special attention should be paid to the legal framework for payments in cryptocurrency (Gimilano, 2016).

\section{References}

Athanassiou, P. (2017). The Impact of Digital Innovation on Payment Processing and contracting: an overview of legal risks. ECB Legal Working Paper Series, 16. https://doi.org/10.2866/201593

Berentsen, A., \& Schär, F. (2018). A brief introduction to the world of cryptocurrencies. Federal Reserve Bank of St. Louis Magazine, 100(1), 1-16. https://doi.org/10.20955/r.2018.1-16

De La Paz, G. A. (2013). Bitcoin, moneta virtuale si mezzo di pagamento reale: l'UE meglio degli USA (In teoria, si) [Bitcoin, virtual currency as a means of real payment: the EU better than the USA (In theory, yes)]. Key4Biz. https://www.key4biz.it/News2013-07-08-Net-economy-Bitcoin-moneta-virtuale-e-mezzo-di-pagamento-reale218903/16978/

European Central Bank. (2012). Virtual Currency Schemes. European Central Bank. https://www.ecb.europa.eu/pub/pdf/other/virtualcurrencyschemes201210en.pdf ?941883c8460133b7758f498192a3ed9e

European Central Bank. (2015). Virtual currency schemes: a further analysis. European Central Bank. https://www.ecb.europa.eu/pub/pdf/other/virtualcurrencyschemesen.pdf 
Gimilano, G. (2016). Bitcoin and Mobile Payments: Constructing a European Union Framework. Macmillan Publisher.

Jabotinsky, H. I. (2018). The Regulation of Cryptocurrencies: Between a Currency and a financial product. Hebrew University of Jerusalem Legal Research Paper, 18(10), 1-39. https://doi.org/10.2139/ssrn.3119591

Luther, W., \& White, L. (2014). Can Bitcoin become a Major Currency?. JMU's work document in economics, 14(17). https://doi.org/10.2139/ssm.2446604

Milcev, A. (2018a). Propunerea Directivei UE privind impozitarea activităților digitale - va fi 2019 anul care va schimba era digitală? [The proposal for an EU Directive on the taxation of digital activities - will 2019 be the year that will change the digital age?]. Ziarul Financiar [Finance newspaper]. https://www.zf.ro/opinii/alexander-milcev-eypropunerea-directivei-ue-privind-impozitarea-activitatilor-digitale-va-fi-2019-anulcare-va-schimba-era-digitala-17783010

Milcev, A. (2018b). 20.000 de plătitori de TVA pot respira uşurați. Comisia Europeana solicită României să pună capăt mecanismului de plată defalcată a TVA [20,000 VAT payers can breathe a sigh of relief. The European Commission is asking Romania to put an end to the broken down VAT payment mechanism]. Ziarul Financiar [Finance newspaper]. https://www.zf.ro/opinii/alex-milcev-ey-romania20-000-de-platitori-de-tva-pot-respira-usurati-comisia-europeana-solicita-romanieisa-puna-capat-mecanismului-de-plata-defalcata-a-tva-17625181

Paunescu, M. (2018a). Exploratory study on accounting and taxation of virtual currencies by Romanian companies. The Audit Financiar journal, 16(150), 239-248. https://doi.org/10.20869/AUDITF/2018/150/009

Paunescu, M. (2018b). The accountant's headache: accounting for virtual currencies transactions. Virtual Currency

Romanian Parliament. (2018). LEGE nr. 225 din 24 iulie 2015 privind anularea contribuției de asigurări sociale de sănătate pentru anumite categorii de persoane fizice [LAW no. 225 of July 24, 2015 on the cancellation of the social health insurance contribution for certain categories of natural persons]. Monitorul Oficial nr. $562 \mathrm{din}$ 28 iulie 2015 [Official Gazette No. 562 of July 28, 2015].

http://legislatie.just.ro/Public/DetaliiDocumentAfis/170102

Romanian Parliament. (2019a). LEGE Nr. 30/2019 din 10 ianuarie 2019 pentru aprobarea Ordonanței de urgență a Guvernului nr. 25/2018 privind modificarea şi completarea unor acte normative, precum şi pentru aprobarea unor măsuri fiscalbugetare [LAW No. 30/2019 of January 10, 2019 for the approval of the Government Emergency Ordinance no. 25/2018 on the amendment and completion of some normative acts, as well as for the approval of some fiscalbudgetary measures]. Monitorul Oficial Nr. 44 din 17 ianuarie 2019 [Official Gazette No. 44 of January 17, 2019]. https://static.anaf.ro/static/10/Anaf/legislatie/L_30_2019.pdf

Romanian Parliament. (2019b). LEGE Nr. 129 din 11 iulie 2019 pentru prevenirea şi combaterea spălării banilor şi finanțării terorismului, precum şi pentru modificarea şi completarea unor acte normative [LAW No. 129 of July 11, 2019 to prevent and combat money laundering and terrorist financing, and to amending and supplementing some normative acts]. Monitorul Oficial nr. 561 din 31 mai 2021 [Official Gazette No. 561 of May 31, 2019]. 
Adriana Monica ȚEGLEDI et al.| Lumen Proceedings 17 | WLC 2021

http://www.onpcsb.ro/pdf/Legea $\% 20129 \% 20 \operatorname{din} \% 202019 \% 20$ \%20forma $\% 20$ in $\% 20$ vigoare $\% 20 \mathrm{de} \% 201 \mathrm{a} \% 2031.05 .2021 \% 20\left(\mathrm{cu}^{2} \% 20\right.$ modif. $\% 20 \mathrm{ad}$ use $\% 20$ prin $\% 200 U G \% 2043 \% 20 \operatorname{din} \% 202021$ )-2.pdf

Tucker, J. (2017). Is there a future for banking in a world dominated by cryptocurrency? NASDAQ. https://www.nasdaq.com/articles/op-ed\%3A-is-there-a-future-for-banking-in-acryptocurrency-dominated-world-2017-10-11

Vardi, N. (2016). Bit by Bit: Assessing the Legal Nature of Virtual Currencies. In G. Gimigliano, Palgrave Macmillan (Eds.), Bitcoin and Mobile Payments. Constructing a European Union Framework, (pp. 55-71). SSRN

Venter, H. (2018). Digital Currency - A Case for Standard Setting Activity. Australian Accounting Standards Board.

Yermack, D. (2013). Is Bitcoin a Real Currency? An Economic Appraisal. NBER Work Paper Series. https://doi.org/10.3386/w19747 